\title{
Improving Junior High School Students' Spatial Reasoning Ability Through Model Eliciting Activities with Cabri 3D
}

\author{
Hartatiana $^{1}$, Darhim ${ }^{2} \&$ Elah Nurlaelah ${ }^{2}$ \\ ${ }^{1}$ Mathematics Education, Islamic State University of Raden Fatah Palembang, Indonesia \\ ${ }^{2}$ Mathematics Education, Indonesia University of Education, Bandung, Indonesia \\ Correspondence: Hartatiana, Mathematics Education, Islamic State University of Raden Fatah Palembang, \\ Indonesia. E-mail: tianaharta@gmail.com
}

Received: May 25, 2017

Accepted: September 22, 2017

Online Published: December 29, 2017

doi:10.5539/ies.v11n1p148

URL: https://doi.org/10.5539/ies.v11n1p148

\begin{abstract}
One of students' abilities which can facilitate them to understand geometric concepts is spatial reasoning ability. Spatial reasoning ability can be defined as an ability involving someone's cognitive processing to present and manipulate spatial figures, relationship, and figure formations. This research aims to find out significant difference on students' spatial reasoning ability between students who are given Model Eliciting Activities with Cabri 3D (MEAC) and those who are only given Model Eliciting Activities (MEA). Quasi experimental design is used in this research which involves 143 junior high school students as the sample. The result of this research shows that students who are given Model Eliciting Activities with Cabri 3D have better spatial reasoning ability than those who are given Model Eliciting Activities. It is suggested for Matematics teachers to implement instruction with Model Eliciting Activities with Cabri 3D.
\end{abstract}

Keywords: spatial reasoning ability, model eliciting activities, Cabri 3D

\section{Introduction}

Geometry has been taught since primary school. Learning geometry helps students develop their logical reasoning ability (Nur'aini, 2012). There are many mathematical concepts and procedures which can be explained by geometry representation. Geometry tends to be abstract which is one of many problems making it difficult to understand. However, with the development of ICT, teachers can choose suitable media for teaching geometry in addition to presenting realistic problems. According to Hershkowitz (2014) since 250 years ago, some aspects of geometry have been developed: (a) interaction with spatial geometry figures. Students learn about length, area, volume, and relations among them; (b) spatial geometry figures and its shape transformation; (c) spatial geomtry figure is as a basic reflection of visual information through reperesntation, explanation, generalization, and documentation.

The implementation of geometry does not only happen in schools but also in daily actvities. It can form students' knowledge about spatial figures and they can apply this knowledge in any fields like design, mechanical engineering, GPS technology, and many others. It also helps them understand other mathematical concepts such as algebra, linear equation, calculus, arithmetic, etc. However, despite the important roles of geometry knowledge, the fact shows that many high school students still experience difficulty in understanding its concepts. A study conducted by Pradika (2012) analyzed students' problems in understanding materials about planes. This study revealed that students had difficulty in the plane visualization especially the shapes, elements, and the nature of planes. These are also confirmed by the observation results in several junior high schools in palembang conducted by the writer which shows students' understanding in geometry is still unsatisfactory. When the students are given a combination of three cuboids with the same length and width but different height which resembles stair steps and they are asked about its surface area, most of the students cannot answer it. They even calculate the surface area by separating the cuboids. In geometry, the ability which can help students to find solution of such mathematical problem is spatial reasoning ability.

Spatial reasoning ability is an ability involving someone's cognitive processing to present and manipulate spatial figures, relationship, and figure formations (Clement and Battista, 1992). In adition, according to National Research Council (2006), it relates to location and movement from a particular object or person physically or 
mentally. Spatial reasoning covers three components namely spatial concept, representation, and reasoning. These components involve relationship among spatial structures and possible representations. This ability invloves spatial visualization and orientation, such as the skill of reading figures and representing 2D figures from 3D figures based on various points of view (Nurlatifah, Wijaksana, \& Rahayu, 2013) and nowadays the awareness of the importance of spatial reasoning ability in Mathematics education is increasing (Khan, Francis, \& Davis, 2014).

There are many softwares provided for teachers to solve mathematical problems and use it in teaching and learning process one of that software is Cabri 3D. Besides use Cabri 3D to improve spatial reasoning ability, a meaningful learning approach is needed, and one of learning approaches is Model Eliciting Activities (MEA). It is one of the mathematical learning approaches which allows students to construct mathematical concepts through realistic problems. Software integration into this approach makes the teaching and learning process more interactive. Students can understand concepts with the help of Cabri 3D. Students also can manipulate and visualize figures through this software.

\section{Research Objective}

This research is aimed to find out is there significant difference on students' spatial reasoning ability between students who are given Model Eliciting Activities with Cabri 3D (MEAC) and those who are only given Model Eliciting Activities (MEA).

\section{Research Method}

This research used quasi experimental design which involves 143 junior high school students as the sample. They are divided into two groups, one group of students is given Model Eliciting Activities with Cabri 3D (MEAC) and the other group is given Model Eliciting Activities. Before the instruction, learning materials and student's workbook are created by the writer for both groups. A test to measure students' spatial reasoning ability is also developed and given before and after learning process.

\section{Result}

Statistical analysis is conducted by firstly testing the normality of the data in order to know whether the obtained data are distributed normally or not. For this purpose, Kolmogorov Smirnov is used with the following hypotheses: $\mathrm{H}_{0}$ : The data are distributed normally and $\mathrm{H}_{1}$ : The data are not distributed normally. The criterion of testing these hypotheses is that if $\mathrm{p}$ value $>0.05, \mathrm{H}_{0}$ is accepted and the other one is rejected and vice versa. The result is diplayed in Table 1.

Table 1 . The result of normality test

\begin{tabular}{lcc}
\hline & \multicolumn{2}{c}{ Instruction } \\
\cline { 2 - 3 } & MEA & MEAC \\
\hline Number of Students & 71 & 72 \\
K-S & 0.651 & 0.651 \\
Asym. Sig & 0.791 & 0.791 \\
H0 & Accepted & Accepted \\
\hline
\end{tabular}

As shown in Table 1, $\mathrm{p}$ value (Sig.) is more than 0.05 . It means $\mathrm{H}_{0}$ is accepted indicating that the data are distributed normally. After normality test, homogeneity test is conducted. The hypotheses are as follows $\mathrm{H}_{0}$ : The data are homogen, $\mathrm{H}_{\mathrm{a}}$ : The data are not homogen. The criterion of testing these hypotheses is that if $\mathrm{p}$ value $>$ $0.05, \mathrm{H}_{0}$ is accepted and the other one is rejected. The result of homogeneity test can bee seen in Table 2 below.

Table 2. The result of homogeneity test

\begin{tabular}{lccccc}
\hline & \multicolumn{2}{c}{ Instruction } & \multirow{2}{*}{ F value } & Sig & $\mathrm{H}_{0}$ \\
\cline { 2 - 3 } & MEAC & MEA & & & \\
\hline Number of Students & 72 & 71 & & & \\
Mean & 0.447 & 0.315 & 8.264 & 0.005 & rejected \\
Std. Dev. & 0.161 & 0.212 & & & \\
\hline
\end{tabular}

As shown in Table 2, p value (Sig.) is lower than 0.05 . It means $\mathrm{H}_{0}$ is rejected indicating that the data are not 
homogen. Due to this result, t'-test is used to see the difference of means.

$\mathrm{H}_{0}$ : there is no significant difference students' spatial reaoning ability improvement between students who are taught by using MEAC and those who are taught by using MEA.

$\mathrm{H}_{1}$ : there is significant difference students' spatial reaoning ability improvement between students who are taught by using MEAC and those who are taught by using MEAC.

If the $\mathrm{p}$ value is more than $0.05, \mathrm{H}_{0}$ is accepted, and if $\mathrm{p}$ value is lower than $0.05, \mathrm{H}_{0}$ is rejected.The result is displayed in Table 3.

Table 3. The result of difference means test

\begin{tabular}{lccccc}
\hline & \multicolumn{2}{c}{ Instruction } & t' value & Sig (2 tailed) & $\mathrm{H}_{0}$ \\
\cline { 2 - 3 } & MEA & MEAC & & & \\
\hline Number of Students & 71 & 72 & & & \\
Mean & 0.315 & 0.447 & -181 & 0.000 & rejected \\
\hline
\end{tabular}

As shown in Table 3, the $\mathrm{p}$ value is lower than 0.05 so that $\mathrm{H}_{0}$ is rejected. Thus, it can be concluded that there is significant difference students' spatial reaoning ability improvement between students who are taught by using MEAC and those who are taught by using MEAC.

\section{Discussion}

The result of statistical analysis shows that there is significant difference on students' spatial reasoning ability improvement between students who are taught by using MEAC and those who are taught by using MEAC. Thus, it can be concluded that MEAC instruction has positive effect on students' activities during the teaching and learning process in the classroom. In other words, MEAC instruction is more effective to improve students' spatial reasoning ability.

The positive result is because MEAC instruction facilitates students to practice and develop their spatial reasoning ability caused by the fact that students are involved directly to undertand the given concepts with visuals in Cabri 3D. It is in line with what Presmeg's statement in Encyclopedia of Mathematics Education (Presmeg, 2014) that visualization in Mathematics is not a new thing as Mathematics uses symbols, diagram, abstract notation which need visualization. Visualization is the ability, process, and product from creation, interpretation in mind. Besides, students are given opportunities to discuss with their classmates, create plans, and determine appropriate steps to solve mathematical problems. This activities also help students enhance their knowledge and reasoning ability.

The finding of this research is in agreement with a reserach conducted by Wulandari (2013) revealing that there was a significant difference in students' learning success between students who were taught by using realstic mathematical instruction with Cabri 3D and those who were not about spatial geometry figures. Besides, Maarif (2015) in his research also claimed that in geometry instruction the use of media such as Cabri II Plus can be used as an effort to improve students' ability in forming geometry evidence. Furthermore, Widiyasari (2013) in her research also mentions that mathematics teaching with Model Eliciting Activities is necessary to implement in schools which results in broader instruction. She also states that there is a need to develop varietied of instruction by using Model Eliciting Activities. This will improve students' ability to master mathematical concepts.

The anlysis result of students' work also shows that they are able to understand line and angle concept well, as shown in Figure 1. The question item and student's answer to see the relationship between figures to determine the angle are as follows:

Item 1: Angle 1 is $95^{\circ}$ and Angle 2 is $110^{\circ}$. What is the measure of Angle 3? 


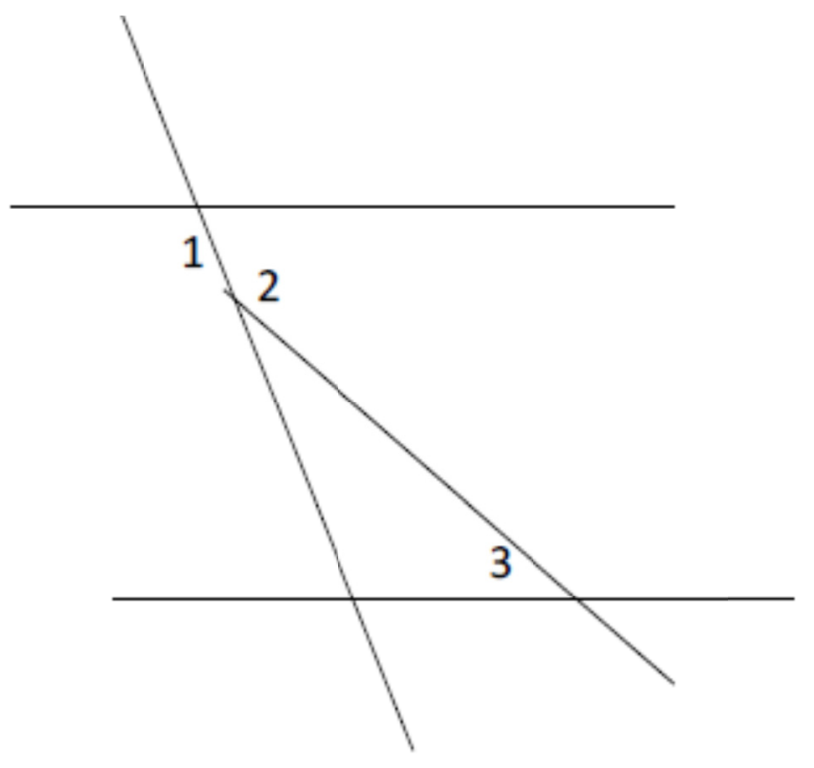

\section{Student's Answer}

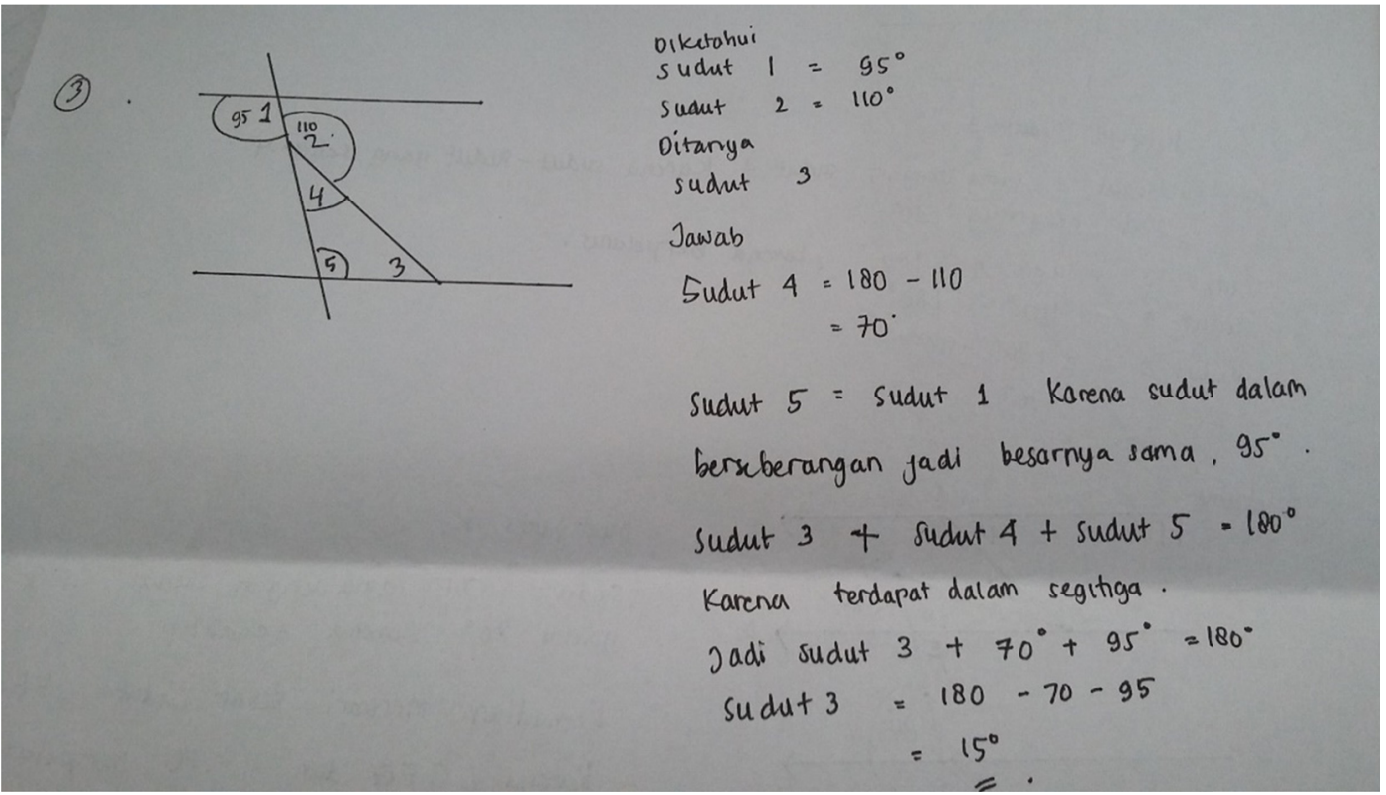

Figure 1. Student's Answer of questions item 1

As shown above, it can be seen that the student undertsands the relationship between angles intersected by a line. In the student's figure, the student states that Angle 1 is the same as Angle 5 due to alternate interior angle. Besides, she also knows supplementary angels and the sum of angles in a triangle. She does not mention which angle supplements another angle. However, in her calculation, she writes that the angle which is $70^{\circ}$ is supplementary to the other angle which is $110^{\circ}$ so that she can determine the angle value which can help her find the answer of the question.

Then, in the question item with indicator which is drawing or designing a geometry figure and representing the line size in the figure and other indicator which is finding out the relation among elements of geometry figure. The question item and student's answer are provided below:

Item 2

a) Draw a cube of KLMN. OPQR with sides $3 \mathrm{~cm}$. 
b) Which line is the intersection between side of PQRO and side of KORN and between side of KLQR and side of MNRQ

\section{Student's Answer:}

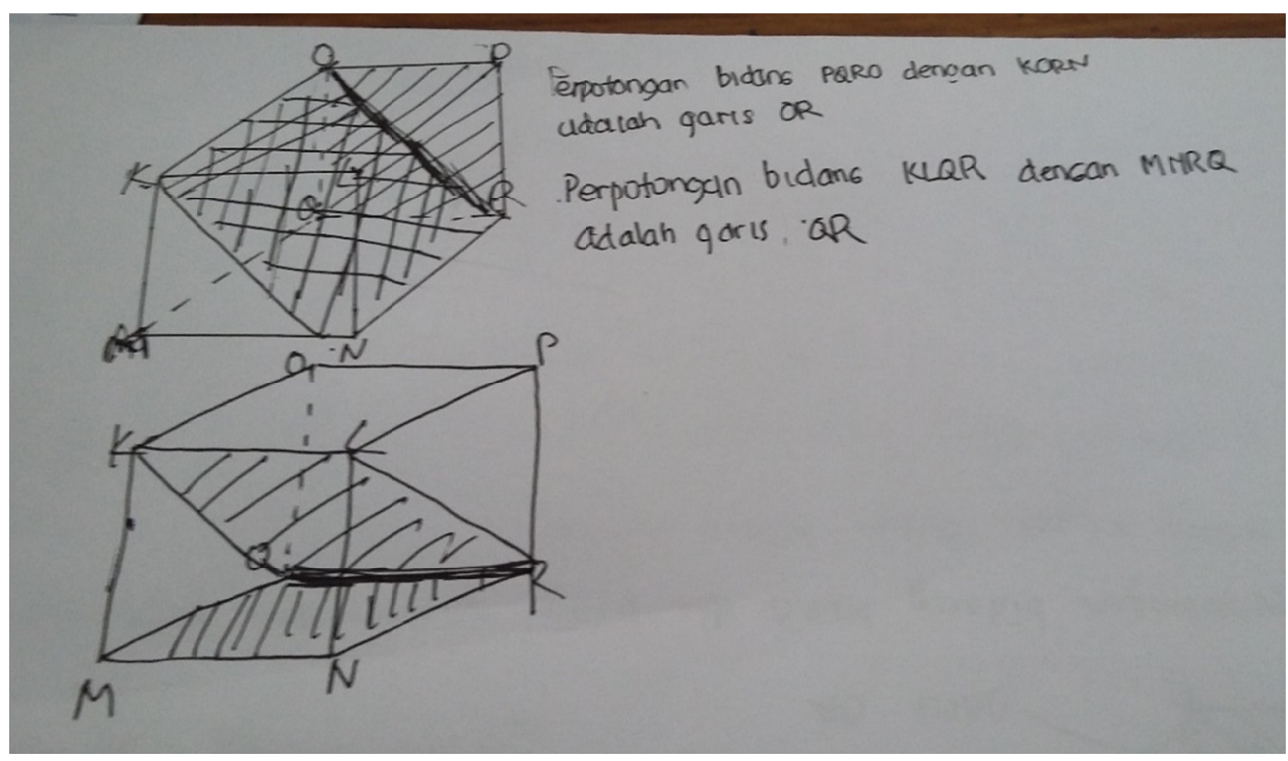

Figure 2. Student's answer of question item 2

As shown in Figure 2, the student is able to draw a cube. Eventhough the cube is not well-drawn yet, she can name the cube correctly so that she can determine the intersection among sides asked in the question.

Next, in the question item below, the indicator is manipulating figure to determine angle.

Item 4: Look carefully at the figure below:

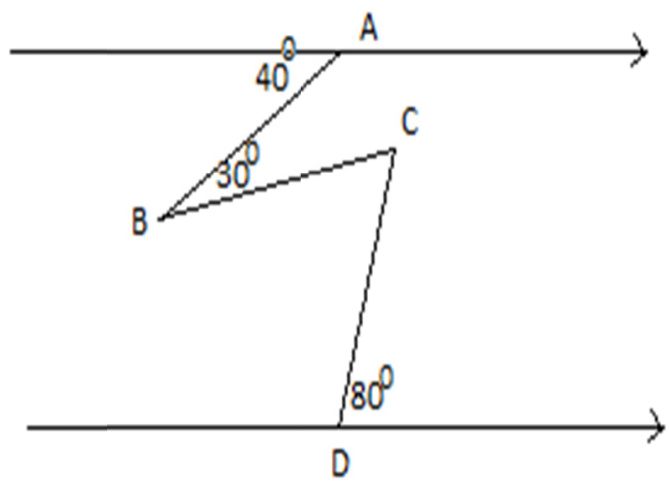

How is the process to find out the measure of angle BDC?

Student's Answer: 


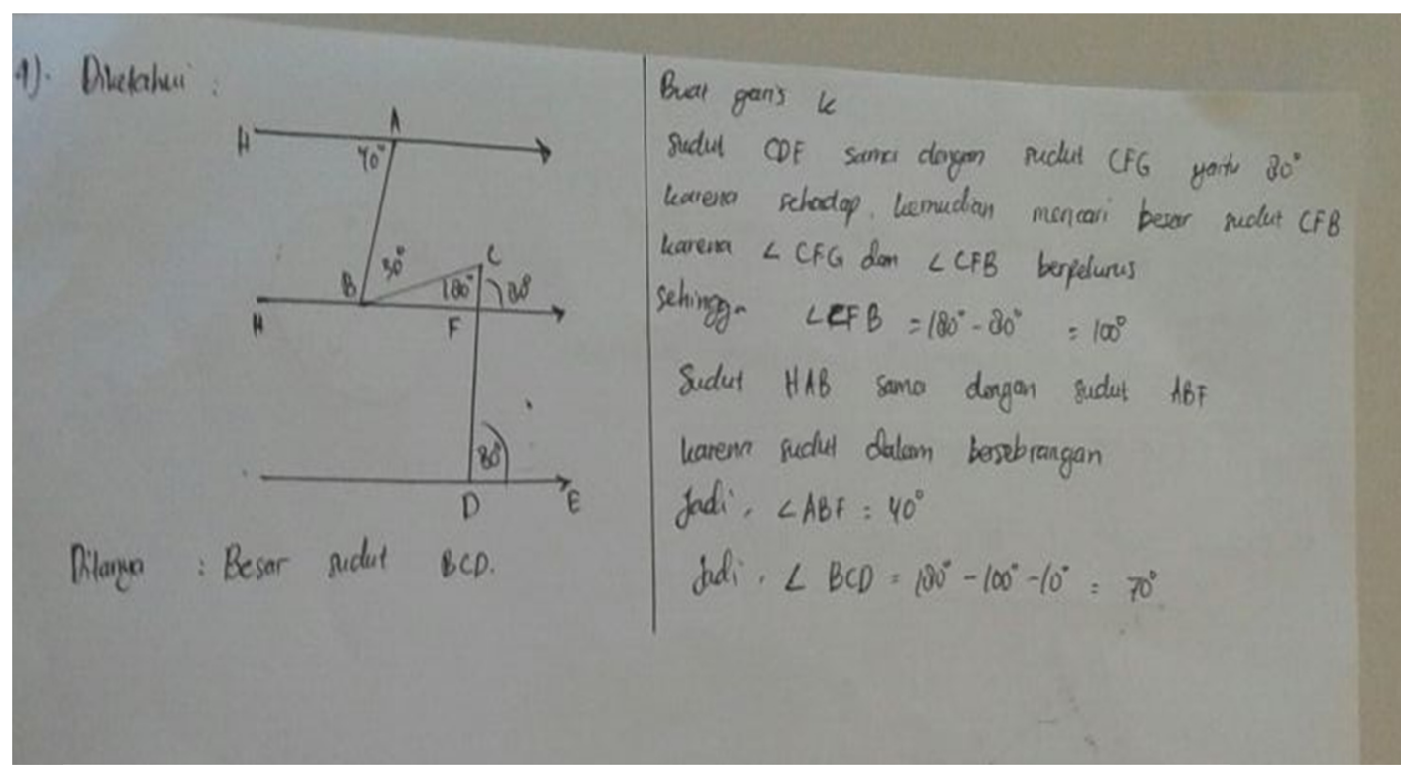

Figure 3. Student's answer of question item 3

As shown in Figure 3, the student can manipulate the picture by adding other line to help her. With this line, she can find the relation between Angle CDE and Angle CFG, namely corresponding angle so that both angles are the same. From the relation, students can determine Angle CFB is supplementary to Angle CFG. Finally, she also knows that the sum of angles of a triangle is $180^{\circ}$ so that she can determine Angle BCD.

\section{Conclusion and Suggestion}

From the results of this research, it can be concluded that students who are given Model Eliciting Activities with Cabri 3D shows better reasoning ability than those who are given Model Eliciting Activities. It is suggested for Matematics teachers to implement instruction with Model Eliciting Activities with Cabri 3D. For better learning outcomes, facilities such as computer laboratorium or notebooks, Cabri 3D software, and other relevant media or references can be used.

\section{References}

Alias, M. (2009). Integrating Technology Into Classroom Instruction for Reduced Misconseptions in Statistics. International Electronic Journal of Mathematics Education, 4(2).

Chamberlin, S. A., \& Moon, S. M. (2005). Model Eliciting Activities as a tool to Develop and Identify Creatively gifted Mathematicians. Journal of Secondary Gifted Education, XVII(1), 37-47. https://doi.org/10.4219/jsge-2005-393

Clement, D., \& Batista, M. (1992). Handbook of research on Mathematics Teaching and Learning: Geometry and Spatial Reasoning. New York: MacMillan Publishing Company.

Daher, \& Shahbari. (2013). Pre-Service Teachers' Modelling Processes Through Engagement With Model Eliciting Activities With A Technological Tool. International Journal of Science and Mathematics Education. National Science Council, Taiwan 2013.

Downs, R. M. (2006). Learning to Think Spatially. Washington DC: The National Academic Press.

Dzulfikar, A. (2012). Keefektifan Problem Based Learning dan Model Eliciting Activities terhadap kemampuan pemecahan masalah. Unner Journal Df. Mathematics Education. Retrieved from http://journal.Unnes.ac.id/id/sju/index.php.ujme

Ekmekci, A., \& Gladys, K. (2011). Model Eliciting Activities (MEAs). $5^{\text {th }}$ Annual Uteach Institute-NMSI Conference Thursday, May 26, 2011.

Hanna, G. (2014). Mathematical Proof, Argumentation, and Reasoning. In S. Lerman (Ed.), Encyclopedia of Mathematics Education (pp. 404-408). http://doi.org/10.1007/978-94-007-4978-8

Hershkowitz, R. (2014). Shapes and Space - Geometry Teaching and Learning. In S. Lerman (Ed.), Encyclopedia of Mathematics Education (pp. 542-547). http://doi.org/10.1007/978-94-007-4978-8 
Khan, S., Francis, K., \& Davis, B. (2014). Accumulation of experience in a vast number of cases: enactivism as a fit framework for the study of spatial reasoning in mathematics education. ZDM Mathematics Education http://doi.org/10.1007/s11858-014-0623-x

Kilpatrick J., Swafford, J., \& Findell, B. (2001). Adding it Up: Helping Children Learn Mathematics. Washington D.C.: National Academy Press.

Koswara, U., Sumarmo, U., \& Kusumah, Y. S. (2012). Mathematical Reasoning and Communication Abilities: Experiment With Grade-10 Student By Using Contextual Teaching Assisted With Autograph Program. Educationist. Jurnal Kajian, Filosopi, Teori, Kualitas, dan Manajemen Pendidikan, VI(2), 125-131.

Lehrer, R., Kobiela, M., \& Weinberg, P. J. (2012). Cultivating Inquiry About Space in Middle School Mathematics Classroom. ZDM Mathematics Education, $465-376$. http://doi.org/10.1007/s11858-012-0479-X

National Council of Teachers of Mathematics. (1989). Curriculum and Evaluation Standards for School Mathematics. Reston. VA: Author.

Nur'aeni, E. (2012). Understanding Geometry and Disposition: Experiment with Elementary Student by Using Van Hiele's Teaching Approach. Educationist. Jurnal Kajian, Filosofi, Teori, Kualitas dan Manajemen Pendidikan, VI, 47-55.

Rososzczuk, R. (2015). Application Of Cabri 3d In Teaching Stereometry. Advances in Science and Technology Research Journal, 9(26), 148-151. http://doi.org/10.12913/22998624/2382

Ruseffendi, H. E. T. (2010). Dasar-dasar Penelitian Pendidikan dan Bidang Non-Eksakta Lainnya. Bandung: Tarsito.

Siregar, I. (2013). Menerapkan pembelajaran menggunakan Model Eliciting Activities untuk Meningkatkan Self Confedence Siswa SMP. KNPM V, Himpunan Matematika Indonesia, Juni 2013.

Yildirim, T. P., Shuman, L., \& Sacre, M. B. (2010). Model Eliciting Activities: Assesing Engineering Student Problem Solving and Skill Integration Process. Int. J. Engineering ed., 26(4), 831-845.

\section{Copyrights}

Copyright for this article is retained by the author(s), with first publication rights granted to the journal.

This is an open-access article distributed under the terms and conditions of the Creative Commons Attribution license (http://creativecommons.org/licenses/by/4.0/). 